\title{
Introduction: Special Issue in Honor of Eva Syková
}

\author{
N. Joan Abbott $^{1}$. Charles Nicholson ${ }^{2}$ [ $\cdot$ Alexei Verkhratsky ${ }^{3}$
}

Received: 27 November 2019 / Accepted: 27 November 2019 / Published online: 20 December 2019

o) Springer Science+Business Media, LLC, part of Springer Nature 2019

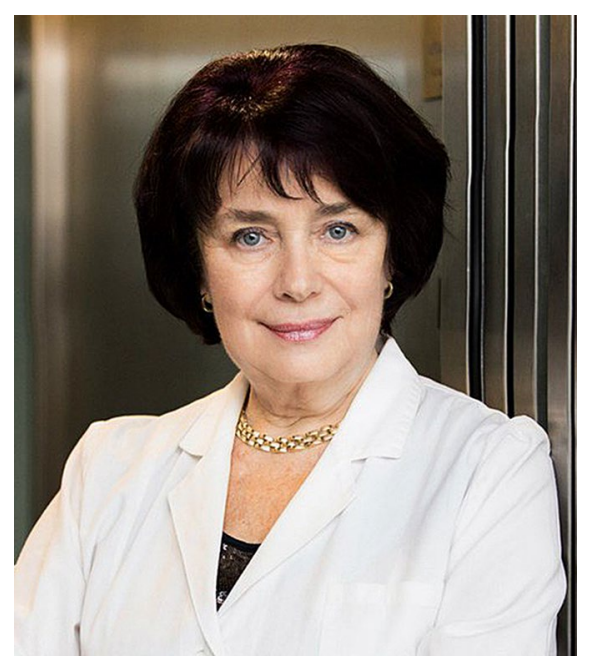

Eva Syková has had an illustrious academic career. It is clear that she was identified as an effective leader early on, and rapidly promoted through the ranks. Many scientists with this degree of responsibility would have given up research as they gained seniority, but Eva has not done this. Instead, she built up an excellent group of co-workers and collaborators, allowing her to continue to be active in research and to incorporate a wide range of topics and experimental studies in her scientific life. Eva's publications show an interest in a variety of topics: sequential, recurring and overlapping. She has more than 350 publications. Eva's most cited papers include an approximately 50:50 split between topics in diffusion/extracellular ion regulation, along with glia, reflecting her earlier studies, and the later work on CNS pathology and

Charles Nicholson

charles.nicholson@nyu.edu

1 Institute of Pharmaceutical Sciences, King's College, London SE1 9NH, UK

2 Department of Neuroscience \& Physiology, NYU School of Medicine, New York, NY 10016, USA

3 Faculty of Biology, Medicine and Health, The University of Manchester, Manchester M13 9PT, UK the possible use of stem cells and advanced biomaterials in CNS repair. In this brief essay, only a few selected publications can be mentioned.

Before starting her formal training, Eva benefited from early research experience in the laboratory of the distinguided Czech neuroscientist, Jan Bureš. Between 1970 and 1983 Eva completed her doctoral and postdoctoral training mostly at the Czechoslovak Academy of Sciences, Prague with an excursion to the University of Goteborg, Sweden, in 1977. From 1983 to 1990 she was Head of the Laboratory of Neurohumoral Regulations, Institute of Physiological Regulations, at the Academy of Sciences. During this period, she managed to be a visiting professor at the University of Heidelberg, Germany (1984) and a visiting Senior Research Fellow at the University of Western Australia, Perth (1985-1986).

Until the Velvet Revolution in 1989, Czechoslovakia was under a Communist regime and quality research was difficult, so the fact that Eva's early papers immediately gained international recognition is a tribute to her drive and ability. In 1993 Czechoslovakia split into the Czech Republic and Slovakia. Meanwhile Eva became Head of the Department 
of Neuroscience, Institute of Experimental Medicine, Academy of Sciences of the Czech Republic (ASCR), Prague in 1991 and from 2001 she rose to the position of Director, Institute of Experimental Medicine ASCR and Principal coordinator for an EU Center for Excellence. Between 1996 and 2012, Eva also was Chair of the Department of Neuroscience, 2nd Medical School, Charles University, Prague. In 2012, Eva's illustrious career took a new direction when she became a Senator in the Parliament of the Czech Republic, a position that she held until 2018. In 2016 Eva retired from the Institute of Experimental Medicine. Characteristically, she continues her academic work on the spinal cord, stem cells and Alzheimer's disease with a position as Senior Researcher at the Institute of Immunology, Slovak Academy of Sciences and as a Scientific Director of a biotechnology company near Prague.

Eva Sykova's early work on the CNS, beginning in 1972 involved cell-cell interaction, including synaptic transmission and changes in extracellular $\mathrm{K}^{+}$, much of it in the spinal cord. Along with her Czech colleagues Vyklický, Křriź and Ujec [1], Eva was a pioneer in the use of ion-selective microelectrodes and co-authored many papers using this technology. By 1980 Eva had begun collaboration on $\mathrm{K}^{+}$ measurements with Dick Orkand [2], already well known in the blood-brain barrier community. Eva's 1983 review [3] on extracellular $\mathrm{K}^{+}$accumulation during neural activity was an important landmark and was expanded into a book in 1992 [4]. In 1980, from July 8-11, she co-organized a conference in Prague on the use of ISMs that also resulted in a co-edited book [5].

About 1980, Charles Nicholson visited Eva's lab in Prague and discovered that Alexandr (Saša) Chvátal was writing a program to analyze diffusion in the extracellular space (ECS). The Nicholson lab in New York already had written such a program called VOLTORO that measured the volume fraction and tortuosity of the extracellular space using the probe ion tetramethylammonium (TMA) and it was decided to use that in Eva's lab. This method became known as the Real-Time Iontophoretic (RTI) method and VOLTORO, and its updates, subsequently played a role in more than 25 of the studies from the Prague laboratory on the diffusion properties in the ECS. This began a scientific interaction and friendship spanning more than 40 years that produced two highly-cited reviews [6, 7]. The RTI work continues today in the laboratory of Lýdia Vargová who heads the Department of Neuroscience at Charles University, Prague.

The extracellular space has been an abiding theme for Eva; in addition to her studies of extracellular $\mathrm{K}^{+}$, she looked at changes in extracellular $\mathrm{pH}$ [8], the development of the ECS [9] and extracellular volume transmission [10]. Volume transmission signifies a process by which an agent released by a neuron or glial cell can travel via the ECS to act at a distance and influence a wider neural territory and was illustrated in detail in the book that Agnati, Fuxe, Nicholson and Syková edited in 2000 [11].

Early on in her career, Eva recognized the importance of glial cells in shaping and modulating the extracellular microenvironment and she has collaborated in experimental studies with several glial experts, including Helmut Kettenmann, beginning in 1987 [12] and in a continuing collaboration with Kettenmann that included Orkand and Chvátal [13] and others [14].

Although Eva has made important contributions to the basic sciences, her abiding focus has been on pathological conditions, both to inform studies on basic research and to extend the reach and relevance to clinical medicine. Eva's papers have included studies relevant to pain [15], neural injury [16], hypoxia and ischemia [17], experimental autoimmune encephalomyelitis (EAE) [18], X-irradiation [19], aging [20], astrogliosis [21], spreading depression [22], hydrocephalus [23], gliomas [24], Alzheimer's Disease [25], epilepsy [26] and extracellular matrix proteins [27].

More recently, Eva has been exploring methods for repairing CNS damage and degeneration. One of Eva's earliest papers on induced neural repair in 1998 [28] involved use of PHPMA hydrogels, followed in 1999 by use of brain grafts [29]. An early stem cell paper [30] used bone-marrowderived stromal cells; later work benefitted from developments in a number of stem cell lines [31]. From this period until the present, Eva has published many papers featuring the use of stem cells in CNS repair, especially in the spinal cord [32], the majority in collaboration with her long-time colleague Pavla Jendelová. Other studies employed artificial biomaterials, often featuring work with Šarka Kubinová [33]. The role of $\mathrm{Ca}^{2+}$ was also investigated in stem-cell treated tissue in collaboration with Alexei Verkhratsky [34].

In this Special Issue, the papers roughly span the evolution of Eva's main areas of interest and include many of her collaborators. Extracellular Space and Volume Transmission are represented by the contributions of Borroto-Escuela and Fuxe [35], Lakatos et al. [36], Lehemenkühler and Richter [37], Nicholson and Kamali-Zare [38], Sherpa et al. [39], and Sucha et al. [40]. Glial Cells are covered by Shulyatnikova and Verkhratsky [41], Smith et al. [42], Stenovec et al. [43], and Verkhratsky and Chvátal [44]. Finally, Injury and Repair feature in the papers of Cizkova et al. [45], Fawcett [46], Jiráková et al. [47], Kubinová [48], Murgoci et al. [49], Roitbak [50], Vymetalova et al. [51], and Wilhelmsson et al. [52].

Eva has also been very active in organizing international symposia in Prague, an excellent way to introduce her teams to the wider community, to develop collaborations, and to show-case novel aspects of the work in Prague. In addition to the first symposium in 1980, mentioned above, they included a workshop from October 23-25, 2001 and another from August 18-31, 2002. The latter was sponsored by IBRO and taught people to use the RTI method for diffusion studies 
on the ECS, as well as other techniques. From July 10-15, 2003, the main IBRO meeting was held in Prague and Eva played a prominent role. This was followed by a symposium in Prague from July 16-17, 2003, which focused on the ECS. Eva's Institute also acted as host for a joint meeting between the Czech and UK Physiological Societies in Prague in 1998.

Joan Abbott recalls that she has a vivid memory of one Prague symposium, in which the 'opening remarks' session started with a curtain around the stage, which swept back to reveal a grand piano-and a pianist then played some beautiful Czech music - a very welcome alternative to the usual introduction at such international meetings by a local dignitary or civil servant. Joan also remembers a gala evening reception where many of the international participants simply turned up in the clothes they had been wearing during the day, including jeans and T-shirts for the younger participants. In contrast, Eva appeared in a long evening dress with a magnificent fur stole!

Eva has been a terrific role model for young women scientists, showing how it is possible to build up and sustain an extremely active research group, gain a well-deserved international reputation for outstanding research, and maintain an excellent reputation as a senior figure and leader in national and international neuroscience studies. And to do all this while maintaining an admirable family life. In the latter she has always been ably supported by her husband, Josef Syka, himself an internationally distinguished neuroscientist in the field of audition. We wish her all the best and hope to continue to meet her at international gatherings.

\section{N. Joan Abbott, Charles Nicholson and Alexei Verkhratsky Guest Editors}

\section{References}

1. Kř̌í N, Syková E, Ujec E, Vyklický L (1974) Changes of extracellular potassium concentration induced by neuronal activity in the spinal cord of the cat. J Physiol 238(1):1-15

2. Syková E, Orkand RK (1980) Extracellular potassium accumulation and transmission in frog spinal cord. Neuroscience 5(8):1421-1428

3. Syková E (1983) Extracellular $\mathrm{K}^{+}$accumulation in the central nervous system. Prog Biophys Mol Biol 42:135-189

4. Syková E (1992) Ionic and volume changes in the microenvironment of nerve and receptor cells. In: Ottoson D (ed) Progress in sensory physiology, vol 13 . Springer, Berlin

5. Syková E, Hník P, Vyklický L (eds) (1981) Ion-selective microelectrodes and their use in excitable tissues. Plenum, New York

6. Nicholson C, Syková E (1998) Extracellular space structure revealed by diffusion analysis. Trends Neurosci 21(5):207-215

7. Syková E, Nicholson C (2008) Diffusion in brain extracellular space. Physiol Rev 88(4):1277-1340
8. Syková E, Svoboda J (1990) Extracellular alkaline-acid-alkaline transients in the rat spinal cord evoked by peripheral stimulation. Brain Res 512(2):181-189

9. Lehmenkühler A, Syková E, Svoboda J, Zilles K, Nicholson C (1993) Extracellular space parameters in the rat neocortex and subcortical white matter during postnatal development determined by diffusion analysis. Neuroscience 55(2):339-351

10. Zoli M, Jansson A, Syková E, Agnati LF, Fuxe K (1999) Volume transmission in the CNS and its relevance for neuropsychopharmacology. Trends Pharmacol Sci 20(4):142-150. https://doi. org/10.1152/physrev.00027.2007

11. Agnati LF, Fuxe K, Nicholson C, Syková E (eds) (2000) Volume transmission revisited, vol 125. Progress in brain research. Elsevier, Amsterdam

12. Kettenmann H, Syková E, Orkand RK, Schachner M (1987) Glial potassium uptake following depletion by intracellular ionophoresis. Pflugers Arch 410(1-2):1-6

13. Chvátal A, Berger T, Vořišek I, Orkand RK, Kettenmann H, Syková E (1997) Changes in glial $\mathrm{K}^{+}$currents with decreased extracellular volume in developing rat white matter. J Neurosci Res 49:98-106

14. Pannasch U, Vargová L, Reingruber J, Ezan P, Holcman D, Giaume C, Syková E, Rouach N (2011) Astroglial networks scale synaptic activity and plasticity. Proc Natl Acad Sci USA 108(20):8467-8472. https://doi.org/10.1073/pnas.1016650108

15. Czéh G, Syková E, Vyklický L (1980) Neurones activated from nociceptors in the spinal cord of the frog. Neurosci Lett 16(3):257-262

16. Svoboda J, Syková E (1991) Extracellular space volume changes in the rat spinal cord produced by nerve stimulation and peripheral injury. Brain Res 560(1-2):216-224

17. Syková E, Svoboda J, Polák J, Chvátal A (1994) Extracellular volume fraction and diffusion characteristics during progressive ischemia and terminal anoxia in the spinal cord of the rat. J Cereb Blood Flow Metab 14(2):301-311

18. Simonová Z, Svoboda J, Orkand P, Bernard CCA, Lassmann H, Syková E (1996) Changes of extracellular space volume and tortuosity in the spinal cord of Lewis rats with experimental autoimmune encephalomyelitis. Physiol Res 45(1):11-22

19. Syková E, Svoboda J, Simonová Z, Lehmenkühler A, Lassmann H (1996) X-irradiation-induced changes in the diffusion parameters of the developing rat brain. Neuroscience 70(2):597-612

20. Syková E, Mazel T, Simonová Z (1998) Diffusion constraints and neuron-glia interaction during aging. Exp Gerontol 33(7-8):837-851

21. Roitbak T, Syková E (1999) Diffusion barriers evoked in the rat cortex by reactive astrogliosis. Glia 28:40-48

22. Mazel T, Richter F, Vargová L, Syková E (2002) Changes in extracellular space volume and geometry induced by cortical spreading depression in immature and adult rats. Physiol Res 51(Suppl 1):S85-S93

23. Syková E, Fiala J, Antonova T, Vořišek I (2001) Extracellular space volume changes and diffusion barriers in rats with kaolininduced and inherited hydrocephalus. Eur J Pediatr Surg 11(Suppl 1):S34-S37

24. Vargová L, Homola A, Zámečník J, Tichý M, Beneš V, Syková E (2003) Diffusion parameters of the extracellular space in human gliomas. Glia 42(1):77-88

25. Syková E, Vořišek I, Antonova T, Mazel T, Meyer-Luehmann M, Jucker M, Hájek M, Or M, Bureš J (2005) Changes in extracellular space size and geometry in APP23 transgenic mice: a model of Alzheimer's disease. Proc Natl Acad Sci USA 102:479-484

26. Kilb W, Dierkes PW, Syková E, Vargová L, Luhmann HJ (2006) Hypoosmolar conditions reduce extracellular volume fraction and enhance epileptiform activity in the CA3 region of the immature rat hippocampus. J Neurosci Res 84(1):119-129 
27. Syková E, Vořišek I, Mazel T, Antonova T, Schachner M (2005) Reduced extracellular space in the brain of tenascin-Rand HNK-1-sulphotransferase deficient mice. Eur J Neurosci 22(8):1873-1880

28. Woerly S, Pinet E, DeRobertis L, Bousmina M, Laroche G, Roitback T, Vargová L, Syková E (1998) Heterogeneous PHPMA hydrogels for tissue repair and axonal regeneration in the injured spinal cord. J Biomater Sci Polym Ed 9(7):681-711

29. Syková E, Roitbak T, Mazel T, Simonová Z, Harvey AR (1999) Astrocytes, oligodendroglia, extracellular space volume and geometry in rat fetal brain grafts. Neuroscience 91(2):783-798

30. Jendelová P, Herynek V, DeCroos J, Glogarová K, Andersson B, Hájek M, Syková E (2003) Imaging the fate of implanted bone marrow stromal cells labeled with superparamagnetic nanoparticles. Magn Reson Med 50(4):767-776. https://doi.org/10.1002/ mrm. 10585

31. Kozubenko N, Turnovcova K, Kapcalova M, Butenko O, Anderova M, Rusnakova V, Kubista M, Hampl A, Jendelova P, Sykova E (2010) Analysis of in vitro and in vivo characteristics of human embryonic stem cell-derived neural precursors. Cell Transpl 19(4):471-486. https://doi.org/10.3727/096368909X 484707

32. Syková E, Homola A, Mazanec R, Lachmann H, Konrádová SL, Kobylka P, Pádr R, Neuwirth J, Komrska V, Vávra V, Štulik J, Bojar M (2006) Autologous bone marrow transplantation in patients with subacute and chronic spinal cord injury. Cell Transpl 15(8-9):675-687

33. Tukmachev D, Forostyak S, Koci Z, Zaviskova K, Vackova I, Vyborny K, Sandvig I, Sandvig A, Medberry CJ, Badylak SF, Sykova E, Kubinova S (2016) Injectable extracellular matrix hydrogels as scaffolds for spinal cord injury repair. Tissue Eng Part A 22(3-4):306-317. https://doi.org/10.1089/ten. TEA.2015.0422

34. Forostyak O, Forostyak S, Kortus S, Sykova E, Verkhratsky A, Dayanithi G (2016) Physiology of $\mathrm{Ca}^{2+}$ signalling in stem cells of different origins and differentiation stages. Cell Calcium 59(23):57-66. https://doi.org/10.1016/j.ceca.2016.02.001

35. Borroto-Escuela DO, Fuxe K (2019) On the G protein-coupled receptor neuromodulation of the claustrum. Neurochem Res. https ://doi.org/10.1007/s11064-019-02822-4

36. Lakatos M, Baranyi M, Eross L, Nardai S, Torok TL, Sperlagh B, Vizi ES (2019) Roles played by the $\mathrm{Na}^{+} / \mathrm{Ca}^{2+}$ exchanger and hypothermia in the prevention of ischemia-induced carrier-mediated efflux of catecholamines into the extracellular space: implications for stroke therapy. Neurochem Res. https://doi.org/10.1007/s1106 4-019-02842-0

37. Lehmenkühler A, Richter F (2019) Cortical spreading depolarization (CSD) recorded from intact skin, from surface of dura mater or cortex: comparison with intracortical recordings in the neocortex of adult rats. Neurochem Res. https://doi.org/10.1007/s1106 4-019-02737-0

38. Nicholson C, Kamali-Zare P (2019) Reduction of dimensionality in Monte Carlo simulation of diffusion in extracellular space surrounding cubic cells. Neurochem Res. https://doi.org/10.1007/ s11064-019-02793-6

39. Sherpa AD, Guilfoyle DN, Naik AA, Isakovic J, Irie F, Yamaguchi Y, Hrabe J, Aoki C, Hrabetova S (2019) Integrity of white matter is compromised in mice with hyaluronan deficiency. Neurochem Res. https://doi.org/10.1007/s11064-019-02819-z

40. Sucha P, Chmelova M, Kamenicka M, Bochin M, Oohashi T, Vargova L (2019) The effect of Hapln4 link protein deficiency on extracellular space diffusion parameters and perineuronal nets in the auditory system during aging. Neurochem Res. https://doi. org/10.1007/s11064-019-02894-2

41. Shulyatnikova T, Verkhratsky A (2019) Astroglia in sepsis associated encephalopathy. Neurochem Res. https://doi.org/10.1007/ s11064-019-02743-2

42. Smith NA, Bekar LK, Nedergaard M (2019) Astrocytic endocannabinoids mediate hippocampal transient heterosynaptic depression. Neurochem Res. https://doi.org/10.1007/s11064-019-02834 $-0$

43. Stenovec M, Bozic M, Pirnat S, Zorec R (2019) Astroglial mechanisms of ketamine action include reduced mobility of Kir4.1carrying vesicles. Neurochem Res. https://doi.org/10.1007/s1106 4-019-02744-1

44. Verkhratsky A, Chvátal A (2019) NMDA receptors in astrocytes. Neurochem Res. https://doi.org/10.1007/s11064-019-02750-3

45. Cizkova D, Murgoci AN, Cubinkova V, Humenik F, Mojzisova Z, Maloveska M, Cizek M, Fournier I, Salzet M (2019) Spinal cord Injury: animal models, imaging tools and the treatment strategies. Neurochem Res. https://doi.org/10.1007/s11064-019-02800-w

46. Fawcett JW (2019) The struggle to make CNS axons regenerate: why has it been so difficult? Neurochem Res. https://doi. org/10.1007/s11064-019-02844-y

47. Jiráková K, Moskvin M, Machová Urdzíková L, Rössner P Jr, Elzeinová F, Chudíčková M, Jirák D, Ziolkowska N, Horák D, Kubinová S, Jendelová P (2019) The negative effect of magnetic nanoparticles with ascorbic acid on peritoneal macrophages. Neurochem Res. https://doi.org/10.1007/s11064-019-02790-9

48. Kubinová S (2019) Biomaterials and magnetic stem cell delivery in the treatment of spinal cord injury. Neurochem Res. https://doi. org/10.1007/s11064-019-02808-2

49. Murgoci AN, Baciak L, Cubinkova V, Smolek T, Tvrdik T, Juranek I, Kafka J, Cizkova D (2019) Diffusion tensor imaging: tool for tracking injured spinal cord fibres in rat. Neurochem Res. https://doi.org/10.1007/s11064-019-02801-9

50. Roitbak T (2019) MicroRNAs and regeneration in animal models of CNS disorders. Neurochem Res. https://doi.org/10.1007/s1106 4-019-02777-6

51. Vymetalova L, Kucirkova T, Knopfova L, Pospisilova V, Kasko T, Lejdarova H, Makaturova E, Kuglik P, Oralova V, Matalova E, Benes P, Koristek Z, Forostyak S (2019) Large-scale automated hollow-fiber bioreactor expansion of umbilical cord-derived human mesenchymal stromal cells for neurological disorders. Neurochem Res. https://doi.org/10.1007/s11064-019-02925-y

52. Wilhelmsson U, Kalm M, Pekna M, Pekny M (2019) Nestin null mice show improved reversal place learning. Neurochem Res. https://doi.org/10.1007/s11064-019-02854-w

Publisher's Note Springer Nature remains neutral with regard to jurisdictional claims in published maps and institutional affiliations. 